that smokers who stop smoking weeks or months before surgery are at an increased risk compared with non-smokers, and patients treated by the routine precautions against postoperative deep vein thrombosis (for example, subcutaneous heparin) should have a lower risk of thromboembolic phenomena.

Firm advice to stop smoking given in a hospital environment and repeated in follow up clinics is very successful in persuading people to stop smoking. ${ }^{33}$ Admission to hospital for surgery, with the general supportive atmosphere and emphasis on health and disease, provides a prime opportunity to persuade people to stop smoking. This opportunity should not be missed just because smokers appear to have a reduced incidence of deep vein thrombosis-a complication amenable to prevention by other means. Advice to patients to stop smoking as long as possible before surgery will undoubtedly benefit them-not only in the short term because of a reduction in perioperative morbidity-but also in the long term because of the risks of chronic pulmonary disease, carcinoma of the lung, and ischaemic heart disease.

In conclusion, roughly six weeks after stopping smoking patients may expect an improvement in pulmonary function, a reduction in postoperative respiratory morbidity, and a return towards normal immune responses. If, however, patients cannot be persuaded to stop smoking for this period (or permanently) considerable benefit will still accrue from the improvement in cardiovascular function brought about by even 12 to 24 hours of abstention from smoking - a factor of particular importance in patients with ischaemic heart disease.

R M JONES

Senior Lecturer in Anaesthetics,

United Medical and Dental Schools of Guy's and St Thomas's Hospitals,

London SE1 9RT

1 Stedman RL. The chemical composition of tobacco and tobacco smoke. Chemotherapy Review 1968;68:153-207.

2 Mitchell C, Garrahy P, Peake P. Postoperative respiratory morbidity: identification and risk factors. Aust NZ J Surg 1982;52:203-9.

3 Borland C, Chamberlain A, Higenbottam T, Shipley M, Rose G. Carbon monoxide yield of cigarettes and its relation to cardiorespiratory disease. $\mathrm{Br} \mathrm{Med} \mathcal{X}$ 1983;287:1583-6.

4 Roughton FJW, Darling RC. The effect of carbon monoxide on the oxyhemoglobin dissociation curve. Am 7 Physiol 1944;141:17-31.

5 Turino GM. Effect of carbon monoxide on the cardiorespiratory system. Circulation 1981;63: 253-9A.

6 Anderson EW, Alderman RJ, Strauch JM, Fortuin NJ, Knelson JH. Effect of low level CO exposure on onset and duration of angina pectoris. Ann Intern Med 1979;79:46-50. 7 Roth GM, Shick RM. The cardiovascular effects of smoking with special reference to

8 Hill D, Larcombe I, Refshauge JG. Smoking and impairment of performance. Med J Aust 1978;ii:60-3.

9 Rode A, Shephard RJ. The influence of cigarette smoking upon the oxygen cost of breathing in near-maximal exercise. Med Sci Sports Exerc 1971;3:51.

10 Seppänen. Physical work capacity in relation to carbon monoxide inhalation and tobacco smoking. Ann Clin Res 1977;9:269-74.

11 Morton HJV. Tobacco smoking and pulmonary complications after operation. Lancet 1944; $368-70$.

12 Wightman JAK. A prospective survey of the incidence of postoperative pulmonary complications. Br f Surg 1968;55:85-91.

13 Laszlo G, Archer GG, Darrell JH, Dawson JM, Fletcher CM. The diagnosis and prophylaxis of pulmonary complications of surgical operation. Br $\mathcal{F}$ Surg 1973;60:129-34

14 Chalon J, Tayyab MA, Ramanathan S. Cytology of respiratory epithelium as a predictor of respiratory complications after operation. Chest 1975;67:32-5.

15 Camner P, Philipson K, Arvidsson T. Withdrawal of cigarette smoking: a study on tracheobronchial clearance. Arch Environ Health 1973;26:90-2.

16 Goodman RM, Yergin BM, Landa JF, Golinvaux MH, Sackner MA. Relationship of smoking history and pulmonary function tests to tracheal mucous velocity in non smokers, young history and pulmonary function tests to tracheal mucous velocity in non smokers, young
smokers, ex-smokers and patients with chronic bronchitis. Am Rev Respir Dis 1978;117:205-14.

17 Chodoff P, Margand PMS, Knowles CL. Short term abstinence from smoking: its place in preoperative preparation. Crit Care Med 1975;3:131-3.

18 Martin RR, Lindsay D, Despas P, et al. The early detection of airway obstruction. Am Rev Respir Dis 1975;111:119-25

19 Buist AS, Sexton GJ, Nagy JM, Ross BB. The effect of smoking cessation and modification on lung function. Am Rev Respir Dis 1976;114:115-22.

20 Corberand J, Nguyen F, Do AH, et al. Effect of tobacco smoking on the functions of polymorphonuclear leukocytes. Infect Immun 1979;23:577-81.

21 Ferson M, Edwards A, Lind A, Milton GW, Hersey P. Low natural killer cell activity and immunoglobulin levels associated with smoking in human subjects. Int f Cancer 1979;23:603-9.

22 Martin RR. Altered morphology and increased acid hydrolase content of pulmonary macrophage from cigarette smokers. Am Rev Respir Dis 1973;107:596-601.

23 Hinman LM, Stevens CA, Matthay RA, Gee JBL. Elastase and lysozyme activities in human alveolar macrophages. Am Rev Respir Dis 1980;121:263-71.
24 Hoidal JR, Fox RB, LeMarbe PA, Perri R, Repine JE. Altered oxidative metabolic responses in vitro of alveoler macrophages from asymptomatic cigarette smokers. Am Rev Respir Dis 1981;123:85-9.

25 Rasp FL, Clawson CC, Hoidal JR, Repine JE. Reversible impairment of the adherence of alveola macrophages from cigarette smokers. Am Rev Respir Dis 1978;118:979-86.

26 Miller LG, Goldstein G, Murphy M, Ginns LC. Reversible alterations in immunoregulatory cells in smoking. Chest 1982;82:526-9.
ciller LG, Goldstein G, Murphy M, Gins

27 Bierenbaum MD, Fleischman AI, Stier A, Somol H, Wabom PB. Effect of cigarette smoking upon in vivo platelet function in man. Thromb Res 1978;12:1051-7.

28 Clayton JK, Anderson JA, McNicol GP. Effect of cigarette smoking on subsequent postoperative thromboembolic disease in gynaecological patients. BrMed f 1978;ii:402.

29 Pollock AV, Evans M. Cigarette smoking and postoperative deep-vein thrombosis. Br Med 1978 ;i: 637.

30 Bucknall TE, Bowker T, Leaper DJ. Does increased movement protect smokers from postoperative deep vein thrombosis. Br Med f 1980;280:447.

31 Handley AJ, Teather D. Influence of smoking on deep vein thrombosis after myocardial

infarction. $B r M e d \mathcal{F} 1974 ;$ iii: $230-1$.
32 Marks $\mathrm{P}$, Emerson PA. Increased incidence of deep vein thrombosis after myocardial infarction in non-smokers. Br Med $\mathcal{f}$ 1974; iii: $232-4$.

33 Burt A, Illingworth D, Shaw TRD, Thornley P, White P, Turner R. Stopping smoking after myocardial infarction. Lancet 1974; i:304-6.

\section{Initiatives in the preregistration year (general clinical training)}

When 12 months of postgraduate extra practical training was introduced in 1953 as a prerequisite for full registration the hope was that this step would allow the undergraduate course to become more truly educative. ${ }^{1}$ That hope seems to have failed, ${ }^{2 a}$ perhaps because of a combination of entrenched attitudes and the ever enlarging undergraduate curriculum, and despite the liberal style of the General Medical Council's recommendations on basic medical education.

Meanwhile, for the past 30 years the training experience of the preregistration year has remained more or less fixed in a pattern of six months' medicine and six months' surgery. This period of so called "general clinical training"' has come to be regarded as a necessary and proper initiation rite for the young doctor. For the first time he comes face to face with life and death issues, for which he now shares some responsibility. He learns to work long hours. In 1980 the GMC's education committee extended its recommendations to cover this period with guidelines concerning patterns of experience and suitability of posts and hospitals and attempted to solve the problems being generated by ever increasing specialisation in medicine and surgery - for example, by providing for a period of training of up to four months spent in general practice within a health centre.

This potential development was an echo of similar and more elaborate proposals generated in the 1960s by medical teachers ${ }^{4}$ and in the 1970 s by the Merrison committee. ${ }^{5}$ The latter proposals-for a two year period of graduate clinical training - had foundered at an early stage, largely because of some medical schools' protests that their five year long curricula (which would have been reduced to four years by the proposals) were solidly established and barely able to accommodate the content already demanded.

In practice, the GMC's encouragement to medical schools to look for new combinations of preregistration experience has led to just one experiment incorporating general practice and this within the University of London at St Mary's Hospital Medical School. A previous experimental post in Southampton in primary care had combined four months in the professorial medical unit and two months in the university health centre linked to a six month post in surgery; but this had faltered-apparently over the issue of prescribing. By contrast, the St Mary's experiment seems to have been highly successful (p 1811). 
The report describes the arrangements made for clinical work, supervision, prescribing, teaching, and also the administrative problems. The general practice house officer worked alongside the general practice trainee in certain respects and seems to have had an ample experience of acute and chronic illness, and some experience of preventive approaches, to have learnt to work in a multidisciplinary fashion, and to have been properly supervised from both legal and educational standpoints. The experiment has been monitored by the regional postgraduate dean, and the complementary medical and surgical house officer posts were solidly embedded in the teaching hospital.

Yet after all these years only one such apparently successful scheme seems to exist. This may reflect resistance to change and to the idea itself (though there are clearly also problems in switching to four monthly from six monthly rotational schemes) and the report from Harris and his colleagues is opportune ( $p$ 1811). Influenced perhaps by its new mood of introspection as well as manpower problems, pressure from the juniors, and public opinion, the medical profession seems now to be thinking that "general clinical training" may no longer be encompassed simply by working within the hospital system in medicine and surgery. Means may need to be devised which will not lengthen training but will nevertheless permit exposure at this stage to subjects such as general practice, obstetrics and gynaecology, laboratory clerkships, psychiatry, and community medicine. This is quite evident from the profession's response to the proposals of the GMC's education committee on basic specialist training, which called for broadening of that next phase. ${ }^{\circ}$

The education committee is currently looking at general clinical training. Any effective proposals for change will have to be practicable in statutory terms as well as acceptable in educational and professional ones. More adequate supervision and guidance may also be necessary during this period. Such supervision might protect the house officer from defensive blunting of his sensitivity to human problems, which may otherwise sometimes be the price to be paid for the traumas of the initiation rite, and which others have perhaps wrongly attributed exclusively to deficiencies of undergraduate training. ${ }^{2}$

The recent tendency has been to blame undergraduate education for inadequacies such as alleged deficiencies in clinical skills when it may be that the preregistration and early specialist training phases are more culpable. With better supervision for preregistration training (and there are resource implications in this) this phase can perhaps become a properly coordinated part of medical education and practice. For instance, at present the trainee starts with a clean sheet on graduation and then finds an abrupt change of responsibility for his medical education at the point of registration; this change may be a block to the idea of continuity in the educational process. It is the GMC's education committee which, since 1978, has been given statutory responsibility for coordinating all stages of medical education. If this can be done then perhaps the undergraduate course may finally be liberated from its present overriding commitment to detail in its many compulsory course units. The detail is often said to stultify creative thinking and problem solving skills, but one of the essential steps in training young doctors is helping them to understand the relation of the minutiae to the whole - an understanding vital to the later tasks of medical practice in both its specialist and generalist forms and presumably also to the ability to adopt when necessary an holistic approach. Yet as things stand at present the young doctor is required to be "complete" by the time of full registration, for this step gives a legal right to practise independently.

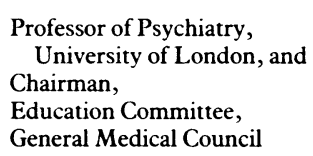

Committee of Inquiry into the Regulation of the Medical Profession. Report. London: HMSO, 1975. (Cmnd 6018.) (Chairman A W Merrison.)

6 General Medical Council. Basic specialist training. A discussion document from the GMC Education Committee. London: General Medical Council, 1983.

\section{Unconventional viruses or prions?}

In his recent book Late Night Thoughts Lewis Thomas made a list of "Seven Wonders of the Modern World." His fourth wonder is the infectious agent commonly known as scrapie virus, which produces a fatal degenerative disease of the central nervous system in sheep and goats-as well as in several laboratory animals such as mice and hamsters. Thomas's decision to place the scrapie agent among his wonders is based on the fact that no nucleic acid has yet been found among the infectious material. Indeed, it has been suggested that the agent may be composed entirely of protein. To quote Thomas, "looked at this way, the scrapie agent seems the strangest thing in all biology. ..."

The disease of sheep, now termed scrapie, was described in the scientific literature of the last century in a Note sur les lésions nerveuses de la tremblante du mouton by Besnoit and Morel. ${ }^{2}$ Only in the past few decades has the agent responsible for the transmission of the disease been recognised as being odd or unconventional. ${ }^{3.5}$ Numerous attempts have been made to define the scrapie agent in terms of its chemical composition and place it alongside other infectious agents such as the viruses of animals and man or the viroids of plants. To date, all efforts to show the presence of a nucleic acid (either DNA or RNA) have completely failed. The agent has proved resistant to all nucleases, to irradiation with ultraviolet light, to divalent cation hydrolysis, to chemical inactivation with agents such as hydroxylamine, and to psoralen photoinactivation. ${ }^{6}$ These are all agents which modify nucleic acids. Most viruses, especially those whose genetic information is contained within relatively low molecular weight DNA or RNA, may prove recalcitrant to one or more of these processes, but no virus has ever before proved resistant to all of them. In this regard the scrapie agent is unique. On the other hand, its infectivity has been shown to be susceptible to numerous processes which inactivate proteins-for example, the hydrolytic activity of trypsin. Experiments such as these have provided the basis for the suggestion that a protein, or proteins, may be exclusively required for infectivity and led to the suggestions of Prusiner that the scrapie agent may be better defined not as a virus but 